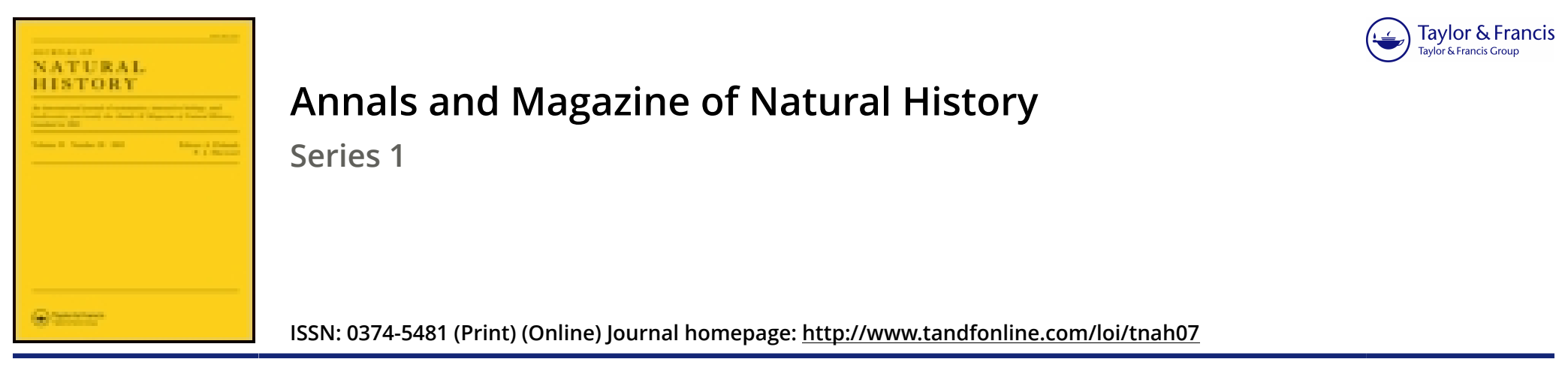

\title{
Do plants placed in a solution containing several substances, absorb certain substances in preference to others?
}

\section{Bouchardat}

To cite this article: M. Bouchardat (1846) Do plants placed in a solution containing several substances, absorb certain substances in preference to others?, Annals and Magazine of Natural History, 18:117, 134-135, DOI: 10.1080/037454809496578

To link to this article: http://dx.doi.org/10.1080/037454809496578

曲 Published online: 23 Dec 2009.

Submit your article to this journal $\pi$

View related articles ๔ 
cloud formed by the living mass, that it completely obscured the sun from people on board our continental steamers on their passage for many hundreds of yards, while the insects strewed the decks in all directions. The flight reached England about twelve o'clock at noon and dispersed themselves inland and along shore, darkening the air as they went. During the sea passage of the butterflies the weather was calm and sunny, with scarce a puff of wind stirring, but an hour or so after they reached terra firma it came on to blow great guns from the S.W., the direction whence the insects came."-Canterbury Journal.

If the time occupied in the passage over could be ascertained it would also be interesting-at all events the hour at which they were observed by the people on board the steamer and the distance from land could be ascertained, and that would go some way towards the rate at which they travelled, the period of their arrival being stated.

I am, dear Sir, yours very truly,

Henry Denny, A.L.S.

Do Plants placed in a Solution containing several Substances, absorb certain Substances in preference to others? By M. Bouchandat.

Theodore de Saussure, who made so many beautiful experiments on vegetation, has answered the question which I have here proposed in the affirmative; but the results which he obtained do not appear to me suficiently free from all chances of error to render it unnecessary to return to this subject. The way in which the experiments of 'Theodore de Saussure were made may be stated in a few words. He dissolved in 793 cubic centimetres of water two or three different salts, each weighing 637 milligrammes; he analysed the residue of the solution when it was reduced one-half by absorption by the roots of the plants. The quantity of salts contained in the residue, minus that which the liquid contained before the introduction of the plants, indicated the quantity of salts absorbed. Theodore de Saussure saw that with several salts this quantity was very unequal; thus, to cite only one example, in a mixed solution of nitrate of lime and muriate of ammonia, a Polygonum absorbed two of nitrate of lime and fifteen of muriate of ammonia.

The differences were particularly great with the soluble salts of lime; their absorption appears infinitely less easy than that of several other salts; but the following experiment throws much doubt on the conclusion to be drawn from the facts cited by Theodore de Saussure.

In a solution in distilled water containing one gramme of sulphate of soda and one gramme of chloride of sodium to the litre, I planted a Polygonum persicaria, and when half the solution was absorbed, I examined the residue, and found in it, besides the oxalate of ammonia, a notable quantity of lime, which did not exist in it previously, and which had been furnished by the vegetable.

This then is one capital cause of error which escaped Theodore de Saussure.

When a vegetable is immersed in an aqueous solution, there is 
not a pure and simple absorption of the solution, but a double current is formed. As the salt of the solution passes into the plant, so the salts of the plant arrive in the solution. This is the principle which M. Dutrochet has so well developed in his excellent investigations on Endosmosis.

There is a strong and a weak current, but always a double current, and not a pure and simple absorption. This cause of error is very important, for Theodore de Saussure operated only upon $637 \mathrm{mil}$ ligrammes, diminished by the fact of the absorption alone, and he did not at all attempt, in his analyses, as may be seen at page 255 of his 'Recherches sur la Végétation,' to find any other principles than those which he wished to estimate ; moreover he has not indicated the weight of the plants he employed.

To avoid, as far as possible, the chances of error caused by the excretions of the roots, I thought that plants should be chosen which, living a considerable time in water, might, by a very long vegetation, be brought into such a condition as no longer to yield any fixed salt to the distilled water, and which would yet possess a marked power of absorption. Mentha aquatica seemed, from numerous previous experiments, to fulfil these conditions much better than the Polygonum persicaria and Bidens cannabina, selected by Theodore de Saussure. The following is the manner in which my experiments were made. Branches of mint, furnished with numerous adventitious roots, which had lived in pure water for more than six months, were placed in flasks containing distilled water which was renewed every five days. When the reagents did not indicate any foreign salt in this water, I made with these plants precisely the same experiments as Theodore de Saussure had done, and I then found, that a vegetable freely immersed by its roots in a very dilute solution of several salts, having no chemical action on its tissues, absorbs all the substances contained in that solution in equal proportions.

. The differences which $I$ have pointed out in my memoir, in the absorption of substances contained in one and the same solution, are too slight for us to admit, with Theodore de Saussure, that the roots select certain salts in a solution in preference to others : that he arrived at different conclusions, results from his having operated only on a few centigrammes of salts in solution, and having omitted to take into account the excretion which is continually going on from the roots simultaneously with the absorption.

The differences observed in analysing the residue of the solutions depend on certain salts being fixed in the plants, either from their concurring in the development of special organs, as the phosphates to that of the grain of the grasses, or from their forming insoluble combinations with some principles of the plant; whilst other substances, which are not subjected to either of these two conditions, are excreted freely by the roots : thus it appears to me that the inverse of Theodore de Saussure's conclusion is correct.

Roots which are immersed in water absorb indifferently all the substances dissolved in this liquid; but the excretions, on the con. trary, may present great differences,-Comptes Rendus, June 8. 
ON A SPECIES OF HIPPOPOTAMUS FROM SIERRA LEONE.

\section{To Richard Taylor, Esq.}

British Museum, 15th July, 1846.

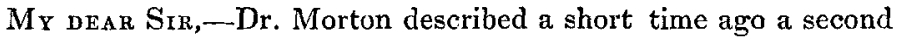
species of Hippopotamus from Liberia, which proves to be most distinct, and is not larger than a calf; by the inclosed note sent me by my friend Colonel Thompson (who, during his governorship of Sierra Leone, paid much attention to natural history, and amongst other things prepared the skeleton of the adult Chimpanzee described by Mr. Owen), it appears that a species about the same size is found in Sierra Leone; at any rate the Sierra Leone animal would be a most interesting addition to our collections. The Wolverine is certainly the Rattel, and the Lemur the Galago.

$$
\begin{aligned}
& \text { Yours very truly, } \\
& \text { To J. E. Gray, Esq. } \\
& \begin{array}{l}
\text { Blackheath, } 12 \text { th July, } 1846 . \\
\text { of }
\end{array}
\end{aligned}
$$

My dear Sir,-In the year 1808 or 1809 , being then Governor of Sierra Leone, I heard of the killing of an animal, which, my impression at the time and ever since was, must have been of the Hippopotamus or Tapir class. It was killed by the Maroons in a stream like a small trout-stream, called the Hog-brook (from the presence of wild hogs), five or six miles inland from Freetown, and now I believe the site of Wilberforce.

I was shown the place to which it retreated and in which it was killed; being precisely such a deep hole as is found every now and then in a trout-stream where the water circles round. 'The place was shown me by Capt. Charles Schaw of the Maroons, a man of excellent character and credit, in whom I should place the most implicit reliance, and who was present at the hunt. He said it was of the size of a small cow (cows are very small at Sierra Leone, and therefore this may be set down as marking the size of one of the smallest cows of the Highland breed); that its skin had only a hair on it here and there, and (I think he added) the skin was black; and that it had " a mouth full of ivory," by which I clearly understood him to mean that it had tusks or projecting teeth.

On recollection I think it was from $\mathrm{Mr}$. Ludlam, my predecessor, that I heard of the killing of the animal, and was afterwards taken to the spot in consequence of my inquiries.

Of curious animals of which I have myself had specimens at Sierra Leone, I will mention the Chimpanzee; Touraco (called by the colonists the Mountain Peacock), Cerastes (of which I have seen three specimens); an animal which I suspected to be of the class of the Wolverine (confirmed by the report of the natives of the country that it threw itself on animals from a tree), remarkable for being divided into black and white by a horizontal line, so that it looked like a creature that had been in the mud (the specimens I saw were about a foot high, but the natives stated that it grew to the size of a goat); and a very beautiful small animal which I suspect to be of 